\title{
RHOB wt Allele
}

National Cancer Institute

\section{Source}

National Cancer Institute. RHOB wt Allele. NCI Thesaurus. Code C52524.

Human RHOB wild-type allele is located in the vicinity of 2 p24.1 and is approximately 53 $\mathrm{kb}$ in length. This allele, which encodes Rho-related GT P-binding protein RhoB, is involved in the mediation of protein trafficking, apoptosis and cellular adhesion. 